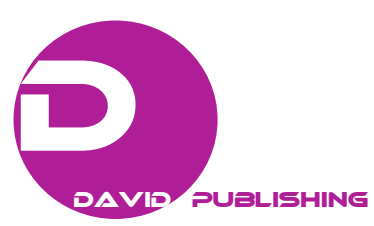

\title{
Desertification and Blown Sand Disaster in China
}

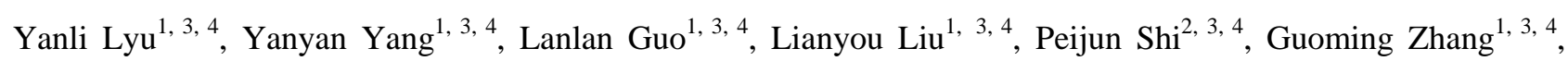
Zhiqiang $\mathrm{Qu}^{5}$, Xia Hu${ }^{1,3,4}$, Jingpu Wang, 3,4 , Yiying Xiong ${ }^{1,3,4}$, Haiming Wen ${ }^{1,3,4}$, Jie Lei ${ }^{1,3,4}$, Bo Liang ${ }^{1,3,4}$ and Jiadong Dai ${ }^{1,3,4}$

1. Key Laboratory of Environment Change and Natural Disaster, Ministry of Education, Beijing Normal University, Beijing 100875, China

2. State Key Laboratory of Earth Surface Processes and Resource Ecology, Beijing Normal University, Beijing 100875, China

3. Academy of Disaster Reduction and Emergency Management, Beijing Normal University, Beijing 100875, China

4. Faculty of Geographical Science, Beijing Normal University, Beijing 100875, China

5. College of Ecology and Environmental Sciences, Inner Mongolia Agricultural University, Huhhot 010019, Inner Mongolia, China

\begin{abstract}
Approximately 331 million ha, one-third of China's total land, is prone to desertification processes, leading to natural disasters and economic losses. In this study, the situation, tendency, their influences and their risk governance of desertification and blown sand disaster in China were examined using satellite images, field photographs, field data and a literature review. The desiccated areas in Lop Nor and the lower Heihe River fluvial plain covered about 50,000 $\mathrm{km}^{2}$ and 40,000 $\mathrm{km}^{2}$, respectively. In Ejina, about 100 species of vegetation became extinct. The rate of wind erosion in China was between 1,000 tons $/ \mathrm{km}^{2} / \mathrm{year}$ and 2,000 tons $/ \mathrm{km}^{2} /$ year. There were 12 sand deserts and sandy lands, occupying a total of 710,000 $\mathrm{km}^{2}$. Salinized soils occurred across 99.1 million ha. The two main sand and dust storm-prone areas in China were the Tarim Basin and its surroundings, and the Alxa Plateau and its surroundings. From 1981 to 2007, the annual average frequency of sand and dust storms varied from $1 \mathrm{~d}$ to $37 \mathrm{~d}$ with a general increase from southeast to northwest. Since 1978, China has implemented a number of ecological construction projects that have reduced desertification from 1999 to 2004 and from 2005 to 2009, and the number of dust and sand storm days from $9.3 \mathrm{~d}$ between 1954 and 1959 to 4.4 d between 2000 and 2007. The results could improve understanding of desertification and blown sand disasters in China and provide valuable experiences for global desertification control.
\end{abstract}

Key words: Desertification, blown sand disaster, desertification and blown sand control, arid and semiarid China, ecological construction project.

\section{Introduction}

China has the largest population and the most serious land degradation in the world [1-3]. Land desertification in arid and semiarid China is the outcome of long-term interactions between natural and social-economic factors [4]. Approximately 331 million ha, one-third of China, is prone to desertification, and the direct economic loss caused by desertification is more than 5.4 billion RMB annually [5]. On the Loess Plateau of China, 4.3 million ha is affected by soil erosion, covering $70 \%$ of the total area of the Loess Plateau, and soil loss in this region

Corresponding author: Lanlan Guo, Ph.D., research fields: desertification and wind erosion. contributes more than $90 \%$ of the total sediments entering the Yellow River [6]. Annually, 1.6 billion tons of sediments are transported from the Loess Plateau to the Yellow River [7]. There is 400 million ha grazing land in China, and 137 million ha is moderately to severely degraded [8]. The total area of degraded grassland increased by about 95\% between 1989 and 1998 [9]. The topsoil thickness progressively declined from the 1930 s to 1950 s, but began to increase again in the 1980s [10]. China's desert lands released 2,168 million tons net of organic carbon from 1960 to 2000; organic carbon release is an important factor affecting changes in concentrations of greenhouse gases [11]. The rapidly expanding population, increasing human land use and 
agricultural development have led to environmental degradation [12]. Over-cultivation on the steppe, overgrazing and forest loss for wood were responsible for $25 \%, 28 \%$ and $32 \%$ of the total area of desertification from the 1950s to 1980s, respectively [13].

A combination of climate change, frequent natural disturbances and growing human activities in arid and semiarid regions has resulted in a decline in soil productivity and vegetation coverage. To address this, the Chinese government has implemented several important ecological construction projects to deal with severe environmental problems, such as desertification, soil erosion and blown sand disasters. These include the Three North Shelterbelt Development Program (3NSDP), the Sand Source Control Program (SSCP) in the vicinity of Beijing and Tianjin, the Grain for Green Project (GGP), the Natural Forest Protection Program (NFPP) and the Grazing Ban for Grassland Restoration Program (GBGRP). Great efforts have been made by Chinese government to combat desertification, and the trend of desertification expansion has been mainly contained, although desertification continues to grow in some regions [5]. Here satellite images, field photographs, data from China Meteorological Administration and State Forestry Administration of China and a literature review were used to discuss the factors influencing desertification and blown sand disasters and their risk governance in China. The results could improve understanding of desertification and blown sand disasters in China and provide valuable experiences for global desertification control.

\section{Situation and Tendency of Desertification in China}

\subsection{Land Desiccation}

Desertification is mainly found in the arid and semiarid regions of China. Based on thermal conditions and humidity, the arid and semiarid regions, which can be classified into temperate arid and semiarid, and cold high arid and semiarid zones with areas of 3.6 million $\mathrm{km}^{2}$ and 1.9 million $\mathrm{km}^{2}$, respectively, cover $57 \%$ of China's total land area. The aridity of Northwest China is chiefly due to its inland position [14]. With the uplift of the Qinghai-Tibetan Plateau, Northwest China has experienced a long history of intensified desiccation [15]. In the past five decades, further land desiccation has been induced by both regional warming and human activities [16]. In the arid regions, farmland expansion and excessive use of limited water resources in the middle and upper reaches of inland rivers led to broad scale land desiccation in Gansu province, Xinjiang and Inner Mongolia. The Lop Nor, a former "wandering" terminal lake of the Tarim River, where ancient oasis civilizations, such as Loulan, once flourished, dried out completely in 1972 $[17,18]$. In the lower Heihe River in Western Inner Mongolia, the terminal lake Gashun Nor exposed its bottom in 1962, and the Sorgo Nor, Guaizi Lake and Gornai Lake suffered the same fate over time [19]. The desiccated areas in Lop Nor and the lower Heihe River fluvial plain cover about 50,000 $\mathrm{km}^{2}$ and 40,000 $\mathrm{km}^{2}$, respectively, and are considered important dust source regions in China (Fig. 1).

\subsection{Vegetation Degeneration and Wind Erosion}

Land desiccation leads to vegetation degeneration and severe wind erosion. Over the past 20 years, the underground water table has fallen by about $5 \mathrm{~m}$ in the lower Heihe Plain. Desert vegetation has died in large areas. In Ejina, about 100 species of vegetation became extinct, and the area of Populus Euphratica declined from $500 \mathrm{~km}^{2}$ in 1949 to $230 \mathrm{~km}^{2}$ in 2002 (Fig. 2a).

Wind erosion is the predominant landform process, and wind erosion features are extensive in arid and semiarid China. The rates of wind erosion in the arid region vary significantly due to the differences in lithology, moisture, land cover and wind regimes [20]. It has been estimated through different methods that 


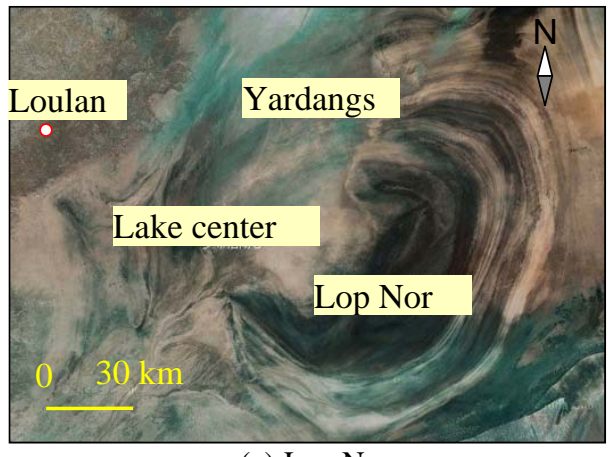

(a) Lop Nor

Fig. 1 Land desiccation in Northwestern China. Source: Google earth.

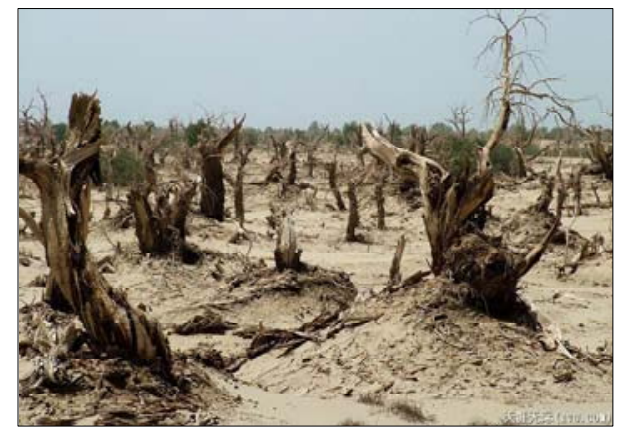

(a) Ghost Forest (4148'29.77" N; 101¹'5.07" E)

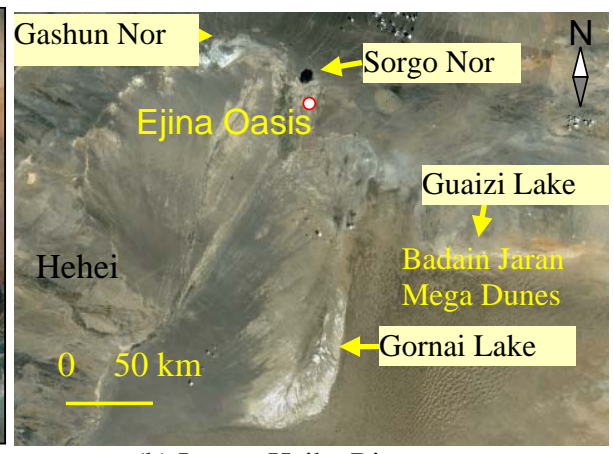

(b) Lower Heihe River

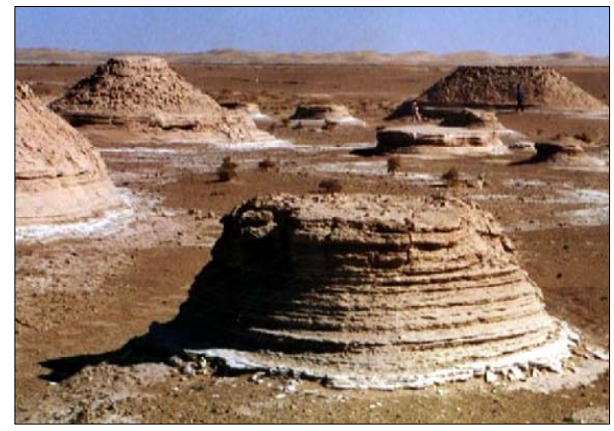

(b) Swan Lake $\left(42^{\circ} 0^{\prime} 42.29^{\prime \prime} \mathrm{N} ; 101^{\circ} 34^{\prime} 15.52^{\prime \prime} \mathrm{E}\right)$

Fig. 2 Vegetation degeneration and wind erosion land form in Northwestern China.

$0.5 \mathrm{~mm}$ to $5 \mathrm{~mm}$ topsoil could be removed by wind every year [21-23]. Studies using the methods of aeolian sand transport, soil texture analysis, Cs-137 tracing and archaeology confirm that the rate of wind erosion is between 1,000 tons $/ \mathrm{km}^{2} /$ year to 2,000 tons $/ \mathrm{km}^{2} /$ year [20]. The 1-2 m high wind eroded clay mesas were shaped by wind action over about 1,000 years, chiefly due to land desiccation influenced by human activities (Fig. 2b).

\subsection{Sandification}

Sandification is a major form of desertification in China. Sandy deserts and sandy lands cover a total of $710,000 \mathrm{~km}^{2}$ [1]. In the arid area to the west of the Helan Mountains, sandification was characterized by vast shifting sandy deserts (Fig. 3). In the semiarid and sub-humid areas to the east of the Helan Mountains, sandy lands were normally fixed or semi-fixed sand dunes. The area of sandification fluctuated due to climatic change and human activities.
Remote sensing analysis showed that the area of sandification in China increased by $33,838.3 \mathrm{~km}^{2}$ from 1975 to 1990 , and $3,441.5 \mathrm{~km}^{2}$ from 1990 to 2000 [24]. Since 2000, there has been a trend of recovery with implementation of the policy of returning farmland to forest, and returning grazed to ungrazed grassland. The area of land sandification decreased by $8,176.4 \mathrm{~km}^{2}$ from 2000 to 2005 and by $5,571.8 \mathrm{~km}^{2}$ from 2005 to 2010 [24]. The changes inland sandification occurred mainly in the agro-pasture ecotone in the semiarid and sub-humid regions, where several ecological construction projects have been carried out over the last decade.

\subsection{Gobi Pebblization}

Gobi pebblization represents a desert pavement, which is land surface with pebbles left by wind deflation or wetting and drying cycles. The coarse pebbles on the Gobi surface protect the land from further erosion. However, coarse pebbles can be easily 


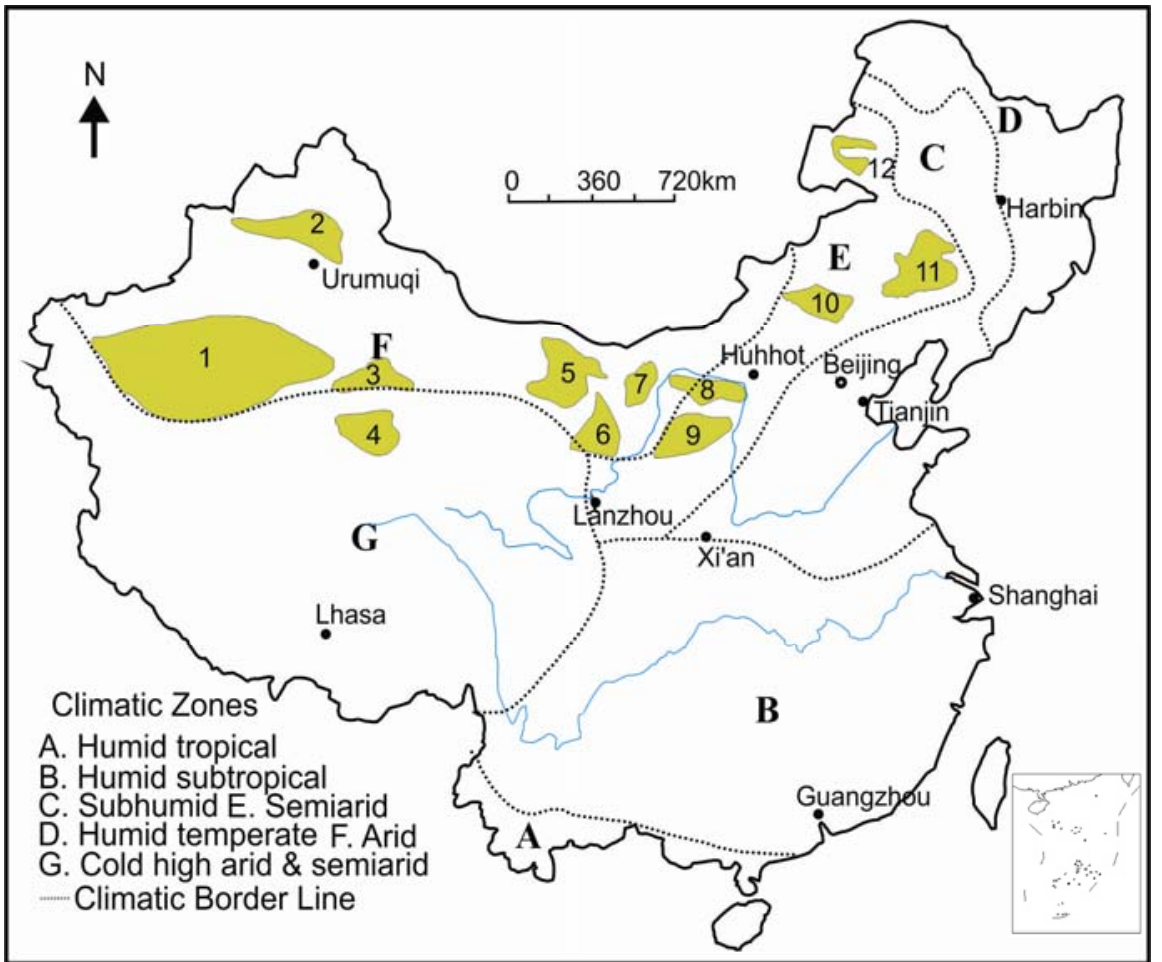

Fig. 3 Climatic zones, sand deserts and sandy lands zones in China.

1: Taklamakan; 2: Gurban Tunggut; 3: Kumtak; 4: Qaidam; 5: Badain Jaran; 6: Tengger; 7: Ulan Buh; 8: Qubqi; 9: Mu Us; 10: Kunshandag; 11: Horqin; 12: Hulun Beir [20].

disturbed and the subsoil can be exposed to further erosion by wind. The area of the Gobi Desert in Northern China is around 569,500 $\mathrm{km}^{2}$ [1]. Along the eastern edge of the Gobi Desert in the Central Inner Mongolian region, interannual variation of the Gobi boundary position has been influenced by climatic change and land-use intensity.

\subsection{Salinization}

Salinization of soils, surface water and ground water is severe in the arid and semiarid areas. Salinized soils in China were mainly found in Inner Mongolia, Gansu, Xinjiang, Qianghai and Tibet. There were 99.1 million ha of salinized soils in China, including recent (36.9 million ha), residual (44.9 million ha) and potential salinized soils (17.3 million ha) [25] (Fig. 4). The water salinity in Qinhai Lake, Bosten Lake and Dalai Nor Lake was 12.9, 1.8, and $5.6 \mathrm{~g} / \mathrm{L}$, respectively [20, 26, 27]. The desiccation of bare saline soils could be a major source of salt dust emissions.

\section{Blown Sand Disaster in China}

Blown sand disasters are caused by various facets of wind-blown sand movement. They can lead to casualties of people and livestock, declining productivity of farmland and grassland, damage to buildings, roads, communications and other facilities, and deterioration of the atmospheric environment. Sand and dust storms have been a notable natural phenomenon in Northern China since ancient times [28]. Increasing human activities have strengthened the combined effect of land desertification and climatic change, enhancing the risk of blown sand disasters in Northern China.

China experiences sand and dust storms every year. From 1981 to 2007, the annual average frequency of sand and dust storms varied from $1 \mathrm{~d}$ to $37 \mathrm{~d}$ with a general increase from southeast to northwest (Fig. 5). The spatial distribution of sand and dust storms in the north of China showed the following characteristics:

(1) Large areas from Xinjiang in the west to the 


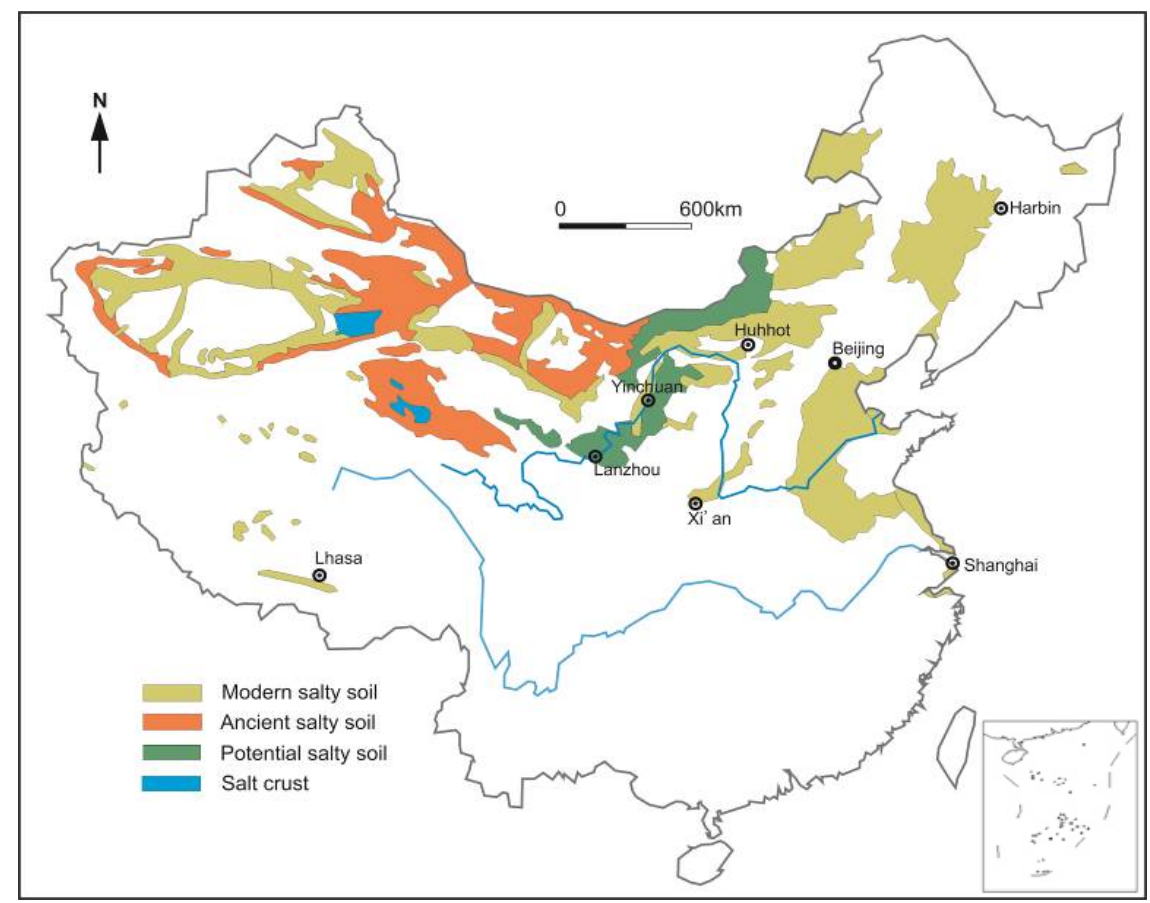

Fig. 4 Salty soils in Northern China [25].

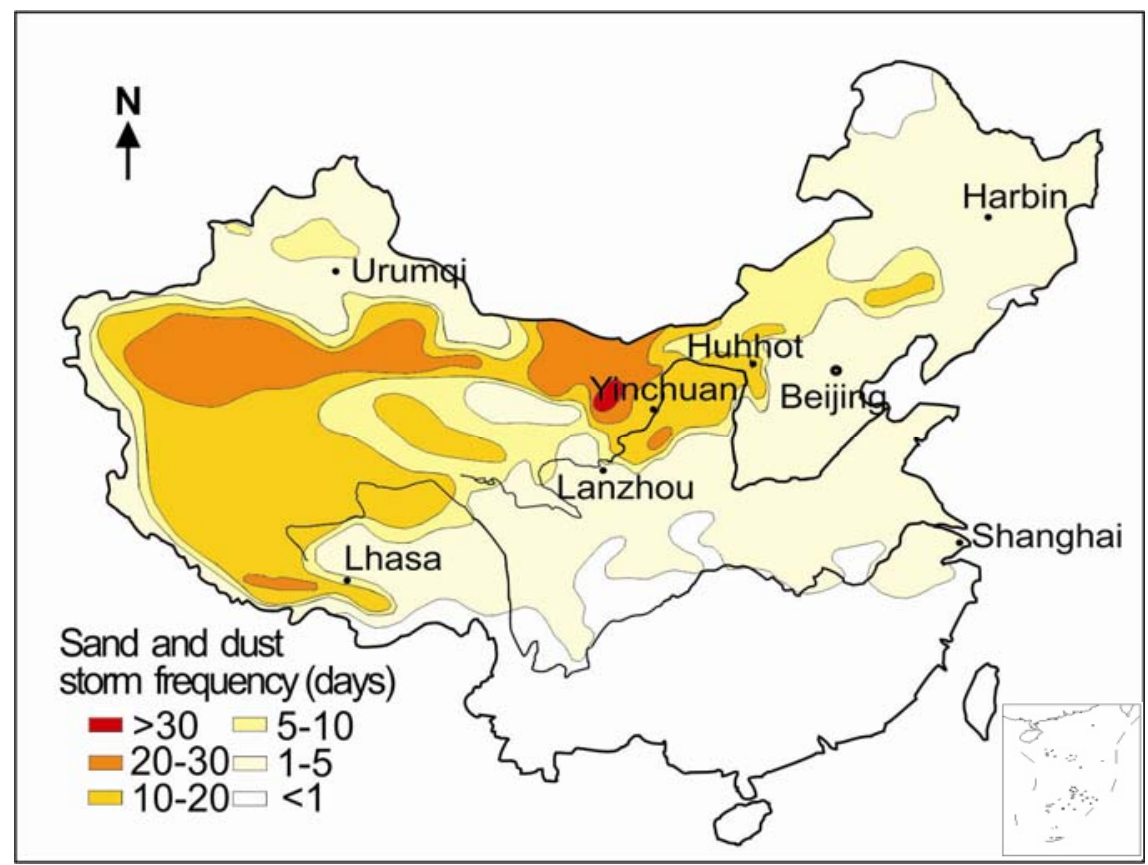

Fig. 5 Annual mean sand and dust storm frequency from 1981 to 2007 in China.

Source: China Meteorological Administration.

coastal regions in the east were affected by sand and dust storms. Thirteen provinces in the north of China were influenced by sand and dust storms to varying degrees;

(2) The sand and dust storm-prone areas were centralized. There were two main areas - the Tarim Basin and its surrounding areas and the Alxa Plateau and its surrounding areas;

(3) There was a close relationship with regional sandification and human activities. The widespread 
desert, sand and farmland surfaces provided extremely rich sand and dust source materials for the formation and development of sand and dust storms.

In total, about 100.7 million people live in China's arid and semiarid dryland areas. Desertification and blown sand disasters lead to damages to traffic and communications, severe atmospheric environmental pollution and widespread dustfall, adverse impacts on land and water resources, and agriculture and animal husbandry (Fig. 6). Extremely strong sand and dust storms, such occurred on May 5, 1993, caused the death of 85 people and the injury of 264 people. Annually, dustfall in continental China due to sand and dust storms was about 400 million tons accounting for $50 \%$ of total dust emissions in China [29].

\section{Countermeasures of Desertification and Blown Sand Disaster in China}

The Chinese government has attached great importance to the prevention of desertification and the governance of blown sand disasters. In the past six decades, China had some successes in blown sand prevention and control measures and technologies, and has developed engineering and biological measures for the prevention and control of blown sand hazards. Since 1978, China has implemented several important ecological construction projects, such as the 3NSDP, GGP, NFPP, SSCP and GBGRP (Table 1).
The 3NSDP, GGP, NFPP and SSCP have restored 26.47, 9.26, 14.0 and 6.0 million ha of forest, respectively. GBGRP has protected 518.66 million ha of grassland with fences and reseeded 12.40 million ha of severe degraded grassland. Ecological restoration programs enhance soil conservation by reducing the amount and velocity of overland water flow as well as the sediment loads on the Loess Plateau [30]. These large-scale programs have not only improved the ecological environment, but also substantially increase forest and soil carbon stocks and sequestration rates at local levels [10, 31, 32]. Liaoning province, where the NFPP has been implemented since 2000, was found to be a carbon sink, with carbon stocks increasing from 63.0 million tons C in 1980 to 120.9 million tons C in 2010, and the average $\mathrm{C}$ density of forest biomass increased from 26.2 ton/ha in 1980 to 31.0 ton/ha in 2010 [33]. Plant biomass after afforestation acted as an important sink for $\mathrm{N}$ and led to an overall increase in $\mathrm{N}$ retention within the system [34]. Data of annual plantation area and biomass $\mathrm{N}$ accumulation rates under the GGP indicated that Guizhou province was a net $\mathrm{N}$ sink with $2.35 \times 10^{8} \mathrm{~kg} \mathrm{~N}$ in 2010 [35]. Moreover, ecological construction projects help local farmers and communities increase agricultural production and escape poverty.

The National Satellite Meteorological Centre of China

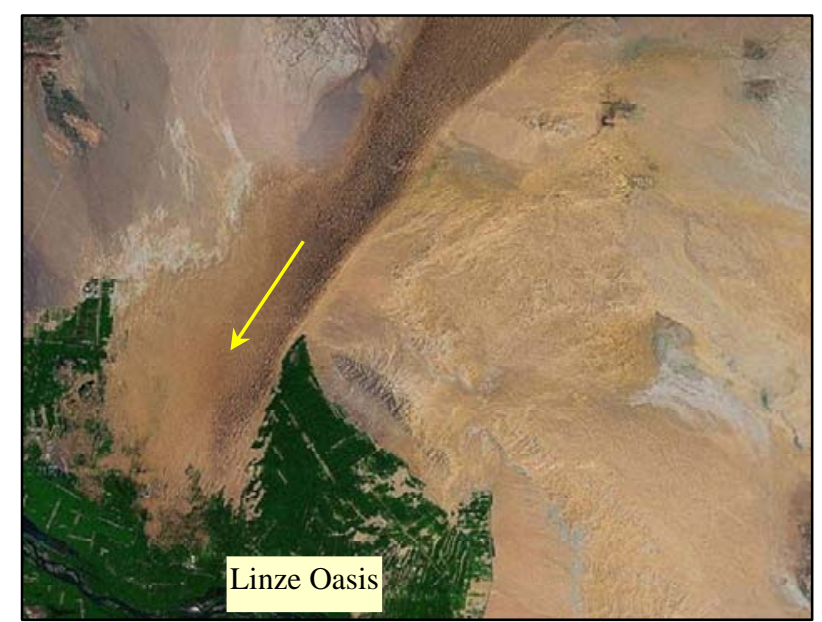

Fig. 6 Sand dunes encroaching from Badain Jaran Desert into Linze Oasis. Source: Google earth. 
Table 1 Government investment in five key forestry and desertification control projects in China.

\begin{tabular}{|c|c|c|}
\hline Key projects & Government investment $\left(\times 10^{8}\right.$ Yuan $)$ & Chief benefits of different projects \\
\hline $\begin{array}{l}\text { 3NSDP } \\
(1978-2010)\end{array}$ & 128 & 26.47 million ha of afforestation land \\
\hline $\begin{array}{l}\text { GGP } \\
(2002-2010)\end{array}$ & 2,332 & 9.26 million ha of cropland was converted into forest land \\
\hline $\begin{array}{l}\text { NFPP } \\
(2000-2010)\end{array}$ & 784 & $\begin{array}{l}\text { Forest area increased by } 14.00 \text { million ha, timber production } \\
\text { reduced by } 220 \text { million } \mathrm{m}^{3}\end{array}$ \\
\hline $\begin{array}{l}\text { SSCP } \\
(2001-2010)\end{array}$ & 412 & 6 million ha of cropland was returned to forest \\
\hline $\begin{array}{l}\text { GBGRP } \\
(2003-2010)\end{array}$ & 203 & $\begin{array}{l}518.66 \text { million ha of grassland was protected with fences and } 12.40 \\
\text { million ha of severe degraded grassland was reseeded }\end{array}$ \\
\hline
\end{tabular}

Source: State Forestry Administration of China.

Table 2 Areas of sandy desertified land in Northern China since 1994.

\begin{tabular}{llll}
\hline Years & Total area of desertified lands (million $\mathrm{km}^{2}$ ) & Total area of sandy desertified lands (million $\mathrm{km}^{2}$ ) & Trend \\
\hline 2009 & 2.624 & 1.7311 & $\downarrow$ \\
2004 & 2.636 & 1.7397 & $\downarrow$ \\
1999 & 2.674 & 1.7431 & $\uparrow$ \\
1994 & 2.622 & 1.7259 & $\uparrow$ \\
\hline
\end{tabular}

Source: State Forestry Administration of China.

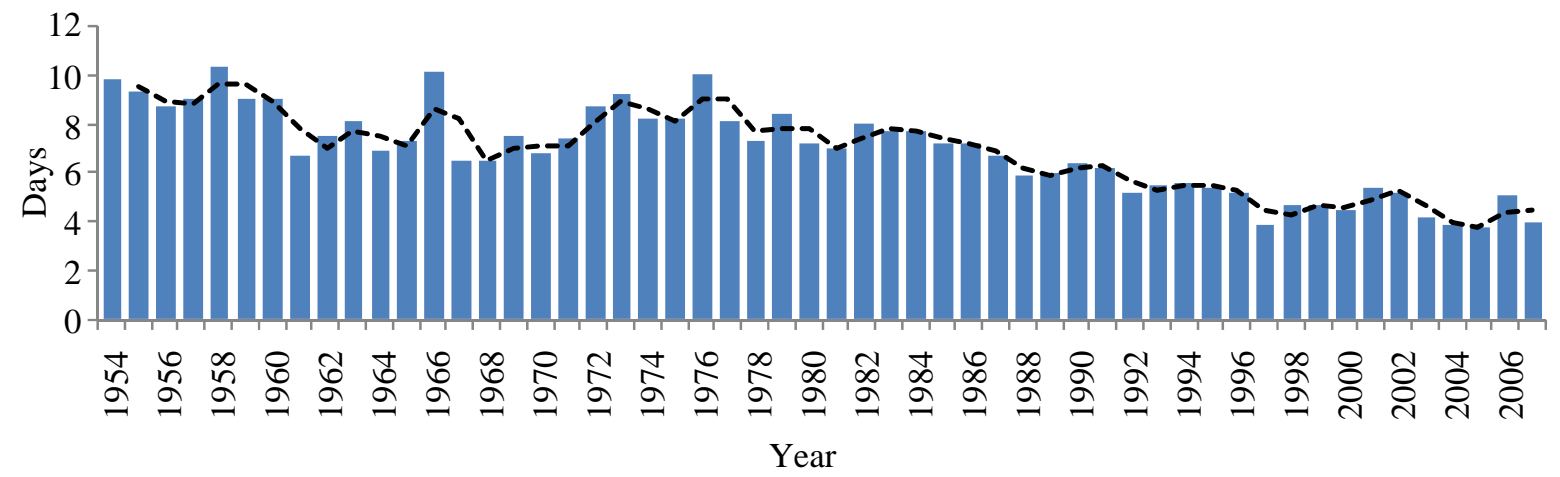

Fig. 7 Changes in sand and dust storm days in Northern China (1954-2007).

Source: China Meteorological Administration. The dashed line is trend line.

Meteorological Administration began to develop a method of satellite-based remote sensing monitoring for sand and dust storms from the 1990s, which mainly uses multi-channel data of polar orbiting meteorological satellites (National Oceanic and Atmospheric Administration/Advanced Very High Resolution Radiometer, NOAA/AVHRR) to identify sand and dust storms. Also, the State Forestry Administration has conducted periodic monitoring on the area of desertified land in China. The monitoring results showed that nationally desertified land area tended to decrease from 1999 to 2004, and from 2005 to 2009 (Table 2). At the same time, there was a decline in the number of sand and dust storm days in
Northern China (Fig. 7). The highest number of sand and dust storm days was $10.3 \mathrm{~d}$ in 1958 . The lowest sand and dust storm day was $3.7 \mathrm{~d}$ in 2005 . Annual sand and dust storm days averaged $9.3 \mathrm{~d}$ between 1954 and 1959, $7.6 \mathrm{~d}$ between 1960 and 1969, $8.2 \mathrm{~d}$ between 1970 and 1979, 7.0 d between 1980 and 1989, $5.2 \mathrm{~d}$ between 1990 and 1999 and $4.4 \mathrm{~d}$ between 2000 and 2007. The variations were related to the meteorological conditions and human activities. In the desertification regions, wind speed decreased significantly from 1960 to 2013 [36]. Decreasing trends in wind speed and ecological constructions led to a decrease in the number of sand and dust storm days. 


\section{Conclusions}

China has the most serious land degradation in the world. The occurrence and development of desertification involve physical, chemical, ecological and human processes, and appear as land desiccation, vegetation degeneration, wind erosion, sandification, Gobi pebblization, salinization and various kinds of blown sand disasters. To combat desertification and blown sand disasters, the Chinese government implemented a series of ecological construction projects. In the past 10 years, positive effects have been seen from these projects, such as vegetation restoration. Lessons learned in practice and ongoing improvements to desertification control in China have provided valuable experience for global desertification control. Continuous monitoring of the spatial and temporal variation of forests and its direct and indirect impacts on ecology and environment is necessary to evaluate the effectiveness and improve the implementations of ecological construction projects.

\section{Acknowledgments}

The authors are grateful to Natural Science Foundation of China (grant No. 41571459), and the Ministry of Science and Technology of China (grant No. 2016YFE0109500) for financial support of this work.

\section{References}

[1] Zhu, Z. D., Wu, Z., Liu, S., and Di, X. M. 1980. Introduction to Sand Deserts in China. Beijing: Science Press. (in Chinese)

[2] Ci, L. J. 1994. "The Impact of Global Change on Desertification in China.” J. Nat. Res. 9: 289-303. (in Chinese)

[3] Zhu, Z. D., and Chen, G. T. 1994. Sandy Desertification in China. Beijing: Science Press. (in Chinese)

[4] Shi, P. J. 1991. Theory and Practice in the Study of Geographical Environment Evolution-Study on Geographical Environment Evolution since Late Quaternary in the Ordos Region. Beijing: Science Press. (in Chinese)

[5] Ci, L., and Yang, X. 2010. Desertification and Its Control in China. New York: Springer.
[6] Chen, L. D., Wei, W., Fu, B. J., and Lü, Y. H. 2007. “Soil and Water Conservation on the Loess Plateau in China: Review and Perspective.” Prog. Physic. Geogr. 31 (4): 389-403.

[7] Wang, H. J., Zhang, S. G., and Ci, F. Q. 1991. Soil Resources and Its Rational Use in Loess Plateau. Beijing: Chinese Scientific and Technical Press. (in Chinese)

[8] World Bank. 2001. "China: Air, Land and Water: Environmental Practices for a New Millennium.” The World Bank. Accessed August 31, 2001. http://documents.worldbank.org/curated/en/16612146874 3733519/China-Air-land-and-water-environmental-priorit ies-for-a-new-millennium.

[9] State Environment Protection Administration (SEPA). 1999. Yearly Report on Environmental Statistics. Beijing: Environmental Science Press. (in Chinese)

[10] Lal, R. 2002. "Soil Carbon Sequestration in China through Agricultural Intensification and Restoration of Degraded and Desertified Ecosystems." Land Degrad. Develop. 13 (6): 469-78.

[11] Feng, Q., Cheng, G. D., and Mikami, M. S. 2001. “The Carbon Cycle of Sandy Lands in China and Its Global Significance.” Climatic Change 48 (4): 535-49.

[12] Xue, Y. K. 1996. "The Impact of Desertification in the Mongolian and the Inner Mongolian Grassland on the Regional Climate.” J. Climate 9 (9): 2173-89.

[13] Zhu, Z., Liu, S., and Di, X. 1989. Desertification and Rehabilitation in China. Beijing: Science Press. (in Chinese)

[14] Cooke, R. U., Warren, A., and Goudie, A. S. 1993. Desert Geomorphology. London: UCL Press.

[15] Zhang, L. Y., and Jiang, Z. L. 1992. "The Genesis of the Arid Climate of Northwestern China.” Arid Land Geog. 15: 1-12. (in Chinese)

[16] Shi, P. J., Sun, S., Wang, M., Li, N., Wang, J. A., Jin, Y. Y., Gu, X. T., and Yin, W. X. 2014. "Climate Change Regionalization in China (1961-2010).” Sci. China Earth Sci. 57 (11): 2676-89.

[17] Zhao, S. Q., and Xia, X. C. 1984. "Evolution of the Lop Desert and the Lop Nor.” Geog. J. 150 (3): 311-21.

[18] Yan, S., Mu, G. J., Xu, Y. Q., and Zhao, Z. H. 1998. "Quaternary Environmental Evolution of the Lop Nur Region, China.” Acta Geog. Sinica 53: 332-40. (in Chinese)

[19] Zhang, Z. K., Wu, R. J., Wang, S. M., Xia, W. L., Wu, Y. H., and Huo, W. C. 1998. "Environmental Changes Recorded by Lake Sediments from East Juyanhai Lake in Inner Mongolia during the Past 2,600 Years.” J. Lake Sci. 10: 44-51. (in Chinese)

[20] Shi, P. J., Shimizu, H., Wang, J. A., Liu, L.Y., Li, X. Y., Fan, Y. D., Yu, Y. J., Jia, H. K., Zhao, Y., Wang, L., and Song, Y. 2005. "Land Degradation and Blown Sand 
Disaster in China.” In Plant Responses to Air Pollution and Global Change. Tokyo: Springer, 261-9.

[21] Hedin, S. 1905. "Lop-Nor." In Scientific Results of a Journey in Central Asia, 1899-1902. Vol. 2, Stockholm: Lithographic Institute of the General Staff of the Swedish Army.

[22] Liu, L. Y. 1999. “The Quantity and Intensity of Regional Aeolian Sand Erosion and Deposition: The Case of Shanxi-Shaanxi-Nei Monggol Region.” Acta Geog. Sinica 54: 59-68. (in Chinese)

[23] Dong, Z. B., Wang, X. M., and Liu, L. Y. 2000. "Wind Erosion in Arid and Semiarid China: An Overview." Journal of Soil and Water Conservation 55 (4): 439-44.

[24] Wang, T., Song, X., Yan, C. Z., Li, S., and Xie, J. L. 2011. "Remote Sensing Analysis on Aeolian Desertification Trends in Northern China during 1975-2010.” J. Desert Res. 31 (6): 1351-6. (in Chinese)

[25] Wang, Z. Q. 1993. Saline Soils in China. Beijing: Science Press. (in Chinese)

[26] Jin, Z. D., Zhang, F., Li, F. C., Chen, L. M., Xiao, J., and He, M. Y. 2013. "Seasonal and Interannual Variations of the Lake Water Parameters and Particle Flux in Lake Qinghai: A Time-Series Sediment Trap Study.” J. Earth Environ. 4: 1306-13. (in Chinese)

[27] Wang, Y. J., Li, Y. A., Wang, Y. G., and Tan, Y. 2005. "Study on the Change of Inflow and Salt Content of the Bosten Lake, Xinjiang since the 1950s.” Arid Zone Res. 22: 355-60. (in Chinese)

[28] Zhang, D. E. 1982. "Analysis of Dust Rain Phenomenon in History.” Chi. Sci. Bull. 5: 294-7. (in Chinese)

[29] Zhang, X. Y., Arimoto, R., and An, Z. S. 1997. "Dust Emission from Chinese Desert Sources Linked to Variations in Atmospheric Circulation.” J. Geophys. Res. 102: 28041-7.
[30] Li, S., Liang, W., Fu, B., Lü, Y., Fu, S., Wang, S., and Su, H. 2016. "Vegetation Changes in Recent Large-Scale Ecological Restoration Projects and Subsequent Impact on Water Resources in China's Loess Plateau.” Sci. Total Environ. 569-570: 1032-9.

[31] Wang, D., Wang, B., and Niu, X. 2014. "Forest Carbon Sequestration in China and Its Benefits.” Scand. J. For. Res. 29 (1): 51-9.

[32] Wei, Y. W., Zhou, W. M., Yu, D. P., Zhou, L., Fang, X. M., Zhao, W., Bao, Y., Meng, Y. Y., and Dai, L. M. 2014. "Carbon Storage of Forest Vegetation under the Natural Forest Protection Program in Northeast China.” Acta Ecol. Sinica 34 (20): 5696-705. (in Chinese)

[33] Yu, D. P., Wang, X. Y., Yin, Y., Zhan, J. Y., Lewis, B. J., Tian, J., Bao, Y., Zhou, W. M., Zhou, L., and Dai, L. M. 2014. "Estimates of Forest Biomass Carbon Storage in Liaoning Province of Northeast China: A Review and Assessment.” PLoS One 9 (2): e89572.

[34] Heilman, B., Makeschin, F., and Rehfuess, K. E. 1995. "Phytosociological Investigations in a Fast Growing Plantation of Poplars and Willows on Former Arable Land.” Forstwiss. Centralbl. 114 (1): 16-29.

[35] Cheng, J., Lee, X., Tang, Y., Pan, W., Gao, W., Chen, Y., Wang, B., and Cheng, H. 2016. "Changes in Above- and Below-Ground Nitrogen Stocks and Allocations Following the Conversion of Farmland to Forest in Rocky Desertification Regions.” Agr. Ecosyst. Environ. 232: 9-16.

[36] Shi, Z. J., Shan, N., Xu, L. H., Yang, X. H., Gao, J. X., Guo, H., Zhang, X., Song, A. Y., and Dong, L. S. 2016. "Spatiotemporal Variation of Temperature, Precipitation and Wind Trends in a Desertification Prone Region of China from 1960 to 2013.” Int. J. Climatol. 36 (13): 4327-37. 